ORIGINAL ARTICLE

\title{
Geostatistical behavior of dendrometric variables of Eucalyptus benthamii for forest management purpose
}

\author{
Comportamento geoestatístico de variáveis dendrométricas de Eucalyptus \\ benthamii para fins de manejo florestal
}

\author{
Laura Camila de Godoy Goergen¹ $\odot$, Igor da Silva Narvaes ${ }^{2} \odot$, David José Miquelutti ${ }^{3} \odot$, \\ Scott X Chang ${ }^{4}$ (), Emanuel Araújo Silva ${ }^{5}$ @ \\ ${ }^{1}$ Departamento de Pesquisa e Monitoramento, Secretaria Municipal do Meio Ambiente - SMMA, Curitiba, PR, Brasil \\ 2 Instituto Nacional de Pesquisas Espaciais - INPE, Coordenação Espacial do Sul - COESU, Santa Maria, RS, Brasil \\ ${ }^{3}$ Universidade do Estado de Santa Catarina - UDESC, Lages, SC, Brasil \\ ${ }^{4}$ University of Alberta - UofA, Edmonton, AB, Canada \\ ${ }^{5}$ Universidade Federal Rural de Pernambuco - UFRPE, Recife, PE, Brasil
}

\begin{abstract}
How to cite: Goergen, L. C. G., Narvaes, I. S., Miquelutti, D. J., Chang, S. X., Silva, E. A. (2020). Geostatistical behavior of dendrometric variables of Eucalyptus benthamii for forest management purposes. Scientia Forestalis, 48(127), e3088. https://doi.org/10.18671/scifor.v48n127.11
\end{abstract}

\begin{abstract}
Resumo
O objetivo deste estudo foi investigar o comportamento das variáveis dendrométricas de um plantio comercial de Eucalyptus benthamii Maiden et Cambage plantado em solo do tipo Inceptisol na região sul do Brasil para fins de manejo florestal, baseado em métricas geoestatística e krigagem ordinária pontual. Foi efetuado um grid amostral de 70 × 70 m de espaçamento em um talhão de 20 ha no município de Bocaina do Sul, Santa Catarina. Cada unidade amostral foi materializada como um círculo de $10 \mathrm{~m}$ de raio, onde foram medidos o diâmetro à altura do peito (dbh), altura total (h) das primeiras 15 árvores e das cinco de maiores diâmetros e o volume individual (v) pelo método de Smalian. As variáveis v, dbh, $h$ e a altura dominante (hdom) de cada unidade amostral foram submetidas à análise geoestatística, baseada nos semivariogramas e na detecção da dependência especial destas variáveis. Somente $h$ e hdom apresentaram ajustes satisfatórios para o semivariograma experimental, onde o modelo esférico representou a variação especial de suas características. Através da krigagem foi possível estimar com alta precisão as variáveis hdom e $h\left(r^{2}=0,97 ; S_{y x}= \pm 0,04 ; r^{2}=0,55, S_{y x}= \pm 0,21\right.$, respectivamente) em sítios não amostrados (dados de validação), fornecendo subsídios para fins de gerenciamento florestal. Entretanto, para dbh e v, é recomendado a realização de maior intensidade amostral para a identificar a continuidade espacial.
\end{abstract}

Palavras-chave: Geoestatística; variabilidade espacial; manejo florestal.

\begin{abstract}
The aim of this study was to investigate the behavior of dendrometric variables of a commercial plantation of Eucalyptus benthamii Maiden et Cambage planted on an Inceptisol soil in Brazil for management purposes, based on geostatistic metrics and ordinary punctual kriging. A sampling grid of $70 \times 70$ m spaced over a 20 ha block was established in the municipality of Bocaina do Sul, in the state of Santa Catarina. Each sampling point was a circular plot of $10 \mathrm{~m}$ radius, where diameter at breast height $(\mathrm{dbh})$, total height $(\mathrm{h})$ of the first 15 trees and the 5 thickest trees were measured and the volume $(\mathrm{v})$ of each tree was calculated by the Smalian method. The variables v, dbh, $\mathrm{h}$ and the dominant height (hdom) of each plot were subjected to geostatistical analysis based on semivariograms to detect the spatial dependence to these dendrometric variables. Only h and hdom presented satisfactory adjustment to the experimental semivariogram, with the spherical model better representing the spatial variation of these
\end{abstract}

Financial support: FAPESC (Foundation for Research and Innovation Support of the State of Santa Catarina) and CAPES (Coordination for the Improvement of Higher Education Personnel).

Conflict of interest: Nothing to declare

Correspondig author: lauragoergen@yahoo.com.br.

Received: 21 September 2018.

Accepted: 02 September 2019.

Editor: Paulo Henrique Müller Silva.

(c) (i) This is an Open Access article distributed under the terms of the Creative Commons Attribution License, which permits unrestricted use,

c) distribution, and reproduction in any medium, provided the original work is properly cited. 
characteristics. Through kriging it was possible to estimate with high precision the variables hdom and $\mathrm{h}$ $\left(r^{2}=0.97, S_{y x}= \pm 0.04 ; r^{2}=0.55, S_{y x}= \pm 0.21\right.$, respectively), in forest sites not sampled (validation data), thus providing subsidies for forest management purposes. Nevertheless, for $\mathrm{dbh}$ and $\mathrm{v}$, it is recommended to conduct a higher sample intensity in order to identify spatial continuity.

Keywords: Geostatistics; spatial variability; forest management.

\section{INTRODUCTION}

The genus Eucalyptus was introduced into Brazil in 1904. In recent years it developed to be an important raw material for supplying the Brazilian and world market for energy, pulp, paper, and solid wood. In 2016, Brazil led the global ranking of forest productivity, with a mean of $35.7 \mathrm{~m}^{3} \mathrm{ha}^{-1}$ per year for eucalyptus plantations (Indústria Brasileira de Árvores, 2017). Investment in technology and research was one of the principal factors responsible for the sector to be leader in the country and in the world.

According to Sanquetta et al. (2009), forest inventory can be considered an indispensable technique to obtain good knowledge about the potential of the existing resources in a certain area; with its main characteristic being the sample representativeness and its statistical validity. However, plot-based forest inventory does not consider the possible correlations between neighboring observations and, therefore, does not sufficiently explore the relationships that may exist between sampling units (Mello et al., 2005). Several studies have shown that the dendrometric variables present spatial dependence, rendering the use of geostatistics to guide management techniques essential (Lundgren et al., 2016; Barni et al., 2016; Souza et al., 2015; Guedes et al., 2015; Ver Hoef; Temesgen, 2013; Mello et al., 2009), specially in large forested areas. Barni et al. (2016) used kriging techniques to model the spatial distribution of biomass stocks and generate a reference map in Brazilian Amazonia, and Amaral et al. (2013) used this same technique to evaluate the influence of a degraded forest with three species in an Ombrophylous Mixed Forest.

Geostatistical techniques can be useful in mapping soil physical and chemical characteristics, mapping and distributing future samples, estimating attributes in unsampled sites, and monitoring existing resources in the area. The semivariance model describes the spatial dependence structure of the indicator variable as a function of distance and direction (the latter if anisotropy is considered) while kriging is a linear spatial interpolator that explicitly accounts for spatial correlation among observations of the variable (De Bruin et al., 2012).

To provide information that can contribute to the development of silvicultural treatments, planning for harvesting and thinning operations, we hypothesize that dendrometric characteristics have spatial dependence and can be interpolated in non-sampled areas. Thus, the aim of this study was to investigate the behavior of dendrometric variables in a Eucalyptus benthamii commercial plantation, for forest management purposes, based on geostatistic metrics and ordinary punctual kriging.

\section{MATERIALS AND METHODS}

The study was conducted in a stand with clonal E. benthamii, located in the municipality of Bocaina do Sul, in the State of Santa Catarina (Figure 1), between coordinates $27^{\circ} 40$ ' 32 " and $27^{\circ} 41^{\prime} ' 13^{\prime \prime}$, southern latitude and $49^{\circ} 52^{\prime}$ ' $42^{\prime \prime}$ and $49^{\circ} 53^{\prime} 04^{\prime \prime}$, west longitude. The selected stand is between 48 and 51 months old, with a spacing of $2.5 \times 3.5 \mathrm{~m}$, and is in its third rotation. 

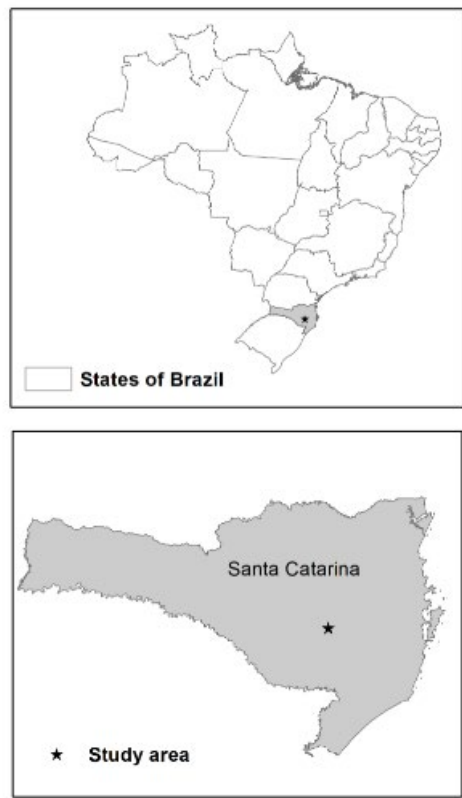

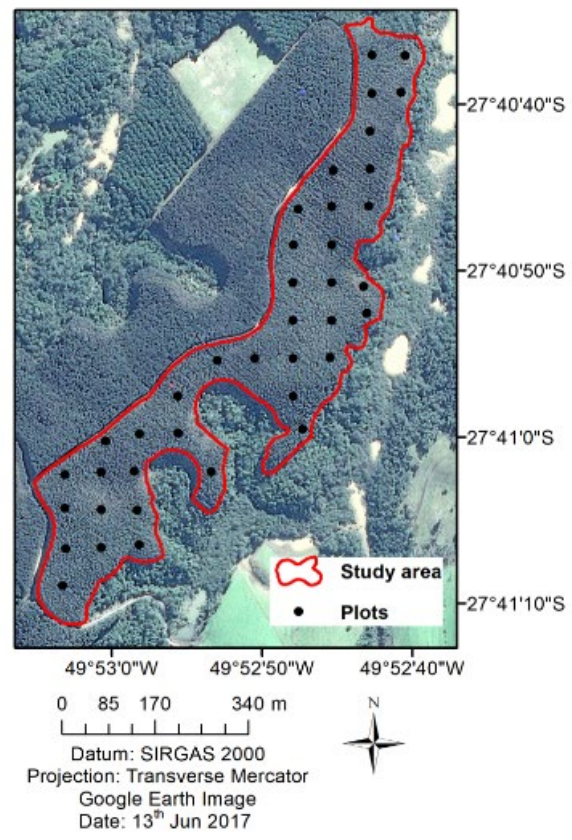

Figure 1. Location of the study area and the sampling grid.

The climate in the region is $\mathrm{Cfb}$, according to the Köppen classification, characterized as a temperate oceanic climate, with an average temperature lower than $18{ }^{\circ} \mathrm{C}$ in the coldest month and less than $22^{\circ} \mathrm{C}$ in the hottest month (Wrege et al., 2012). The soil classification according to the Brazilian System of Soil Classification is Cambissolo Húmico Alumínico (Santos et al., 2013) and Inceptisol in Soil Taxonomy, with an incipient B horizon (Soil Survey Staff, 2014). The relief consists of wavy and mountainous surfaces with an altitude ranging from $800 \mathrm{~m}$ to $1800 \mathrm{~m}$. In the stand, seedlings of the same species and of the same age were planted, resulting in an even-aged stand. No management techniques such as pruning and thinning were applied. In addition, the plot was free from weed competition, pests, and damages caused by fire or wind (Figure 2).

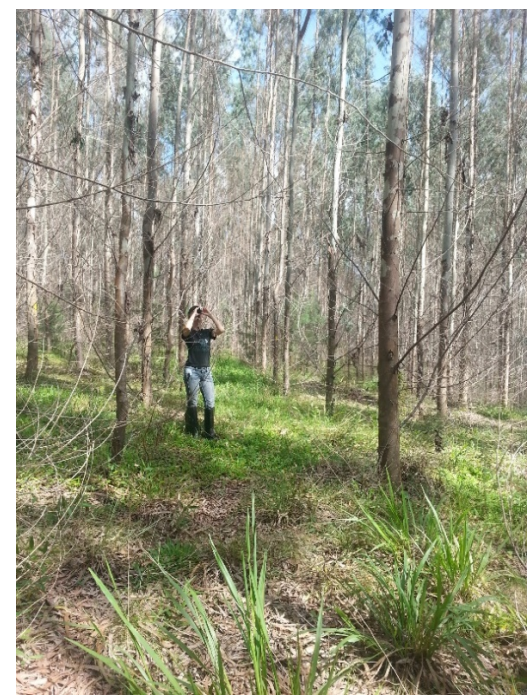

Figure 2. Overview of the eucalyptus forest.

The sampling units were structured from a systematic and quadrangular sampling grid at intervals of $70 \mathrm{~m}$ between the plots using the software ArcMap 10.3 (Environmental Systems Research Institute, 2013). The measured 20.07 hectares, with 39 plots sampled, with a $10 \mathrm{~m}$ 
radius $\left(314 \mathrm{~m}^{2}\right)$ each. Within each plot, the diameter at breast height (dbh) of all individuals was measured, and the total height of the first 15 trees and the 5 thickest trees for the calculation of the dominant height, according to the concept of Assmann (Prodan et al., 1997), which considers as the average height the 100 largest diameter trees in one hectare. The heights were measured with a Vertex IV hypsometer and the coordinate values of each sampling point were obtained accurately using the Trimble Juno GPS (Trimble, USA), with a precision from 1 to 3 meters after post-processing.

For the inventory processing, the FlorExel program (Arce et al., 2002) was used; the total height (h) of the trees was estimated by the linear, polynomial, logarithmic, logarithmic regression models, and Prodan functions. The best model was selected based on the coefficient of determination $\left(r^{2}\right)$ and the standard error of the estimate $\left(S_{y x}\right)$ (Equation 6).

The accurate scaling of the trees was performed by the Smalian method, which consists in taking the measures of the tree circumference at the lengths of $0.7,1.3$ and $2.0 \mathrm{~m}$, and then every two meters until to the end of the stem of the tree.

To calculate the assortment, the fifth-degree polynomial was used (Schöpfer, 1966). The fifth-degree polynomial is the best-known taper function in southern Brazil and has been frequently used in forest inventories when the objective is to quantify multi-product and to evaluate the evolution of trunk shape with advancing age (Figueiredo Filho et al., 2015). To obtain the total stem volume $\left(v\right.$, in $\left.\mathrm{m}^{3}\right)$, it is necessary to integrate the stem's sections between the lower $\left(h_{1}=0\right)$ and upper bound $\left(h_{2}=\right.$ total tree height), according to Equation 1.

$v=K \int_{h_{l}}^{h_{2}} d_{i}^{2} \delta h$

where: $v=$ volume in $\mathrm{m}^{3} ; K=\pi / 40,000 ; d_{i}=$ diameter corresponding to any height $\left(h_{i}\right)$ along the stem.

The mean height and the mean dominant height, both estimated per plot, the mean $\mathrm{dbh}$ and the estimated volume (at plot level) were used for kriging modeling. The descriptive statistical analysis of the data was performed using the program R (R Core Team, 2018). Subsequently, geostatistical analysis was performed in GS + (Robertson, 2008) to verify the existence of spatial dependence and, when applicable, to quantify the degree of spatial dependence of the studied variables, from the adjustment of theoretical models to the semivariograms (Equation 2):

$$
\gamma(d)=\frac{1}{2 N(d)} \sum_{i=1}^{n(d)}\left[Z\left(x_{i}\right)-Z\left(x_{i}+d\right)\right]^{2}
$$

where: $y(d)$ is the estimated semivariance at a separation distance, or lag $d ; z\left(x_{i}+d\right)$ is the value of the variable at the point $x_{i}+d ; Z\left(x_{i}\right)$ is the variable value at the point $x_{i}$ and; $N(d)$ is the number of pairs separated by a distance $d$ and $x_{i}$ (Cressie, 1993).

Semivariograms were computed using active lag distance (the maximum spacing between data points used in the analysis, a distance constrained by field dimensions) out to $400 \mathrm{~m}$ for all variables. The values established for active lag distance and lag class distance interval are reasonable because there were sufficient pairs of observations available for each lag spacing $(>30)$ for the variogram to be representative of the whole sampling space and with statistical reliability in each distance class (Schabenberger And Gotway, 2017).

The theoretical models tested were spherical (Equation 3), exponential (Equation 4) and Gaussian (Equation 5) (Robertson, 2008)

$$
\gamma(d)_{e s f}=\left\{\begin{array}{cc}
C_{0}+C\left[\left(\frac{3}{2}\right)\left(\frac{d}{A}\right)-\left(\frac{1}{2}\right)\left(\frac{d}{A}\right)^{3}\right], \text { for } d \leq A \\
C_{0}+C, \quad \text { for } d>A
\end{array}\right.
$$




$$
\begin{aligned}
& \gamma(d)_{\exp }=C_{0}+C\left(1-e^{d / A}\right) \\
& \gamma(d)_{g a u}=C_{0}+C\left(1-e^{d^{2} / A^{2}}\right)
\end{aligned}
$$

where: $C_{0}$ is the nugget effect; $C_{0}+C$ is the sill; $d$ is the distance between two points and $A$ is the range of spatial dependence.

The adjustment of semivariograms models allowed to define the following parameters: nugget effect $\left(C_{0}\right)$, sill $\left(C_{0}+C\right)$, range $\left(A_{0}\right)$ and the degree of spatial dependence (DSD). The DSD is calculated by the relationship between the nugget effect and the sill, classified as high if it is less than $25 \%$, medium if the values are between $25 \%$ and $75 \%$ and low spatial dependence if the value is greater than 75\% (Cambardella et al., 1994). The occurrence of anisotropy was evaluated from the construction of the four directional semivariograms with $0{ }^{\circ}, 45^{\circ}, 90^{\circ}$ and $135^{\circ}$ for each variable, considering the parameters of nugget effect, sill and range. When the semivariograms have similar parameters, the anisotropy is discarded.

The choice of the most appropriate model was based on the highest coefficient of determination of the semivariogram $\left(r^{2}\right)$ and the lowest sum of squares of the residue (SQR). The cross-validation, which compares observed and estimated values, was used to test kriging estimates.

According to Robertson (2008), in the cross-validation analysis (Leave-one-out), each measured point in the spatial domain is removed individually from the domain and its estimated value, as if it had never existed. Then the point is replaced, and the next point is removed and estimated, and so on. We compared the models through the coefficient of regression which represents a measure of the goodness of fit for the least-squares model describing the linear regression equation (Robertson, 2008); the standard error refers to the standard error of the regression coefficient and the $y$-intercept of the best-fit line.

The GS + program applies the method of Least Squares to fit the models and uses the coefficient of determination $\left(\mathrm{R}^{2}\right)$ and the sum of squares of residuals (RSS) as criteria for model selection.

In the presence of spatial dependence (high DSD\%) and based on the parameters of the adjusted semivariograms, the data were interpolated to the locations not sampled by the kriging method as proposed by Amaral et al. (2013), and the thematic maps were made, establishing the pixel size of $17.7 \mathrm{~m}$, resulting in an approximate dimension $\left(314 \mathrm{~m}^{2}\right)$ of the sample unit. Figure 3 depicts the general approach used in this study.

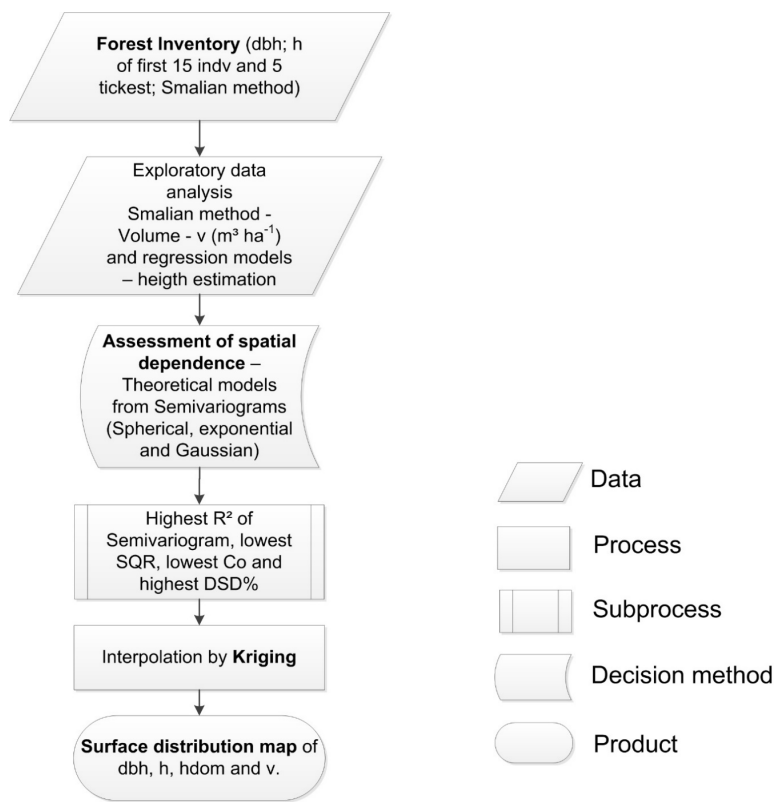

Figure 3. Assessment method for forest management purposes. 


\section{RESULTS AND DISCUSSION}

Equation 6 presented the best fit for the tree height estimation, with $r^{2}$ equal to 0.63 and $S_{y x}$ equal to $\pm 1.9 \mathrm{~m}$.

$h=-2.0693+2.5391 d b h-0.0602 d b h^{2}$

where:

$h$ is the height $(\mathrm{m}), d b h$ is the diameter $(\mathrm{cm})$ at breast height at $1.30 \mathrm{~m}$ from the ground.

The scaling allowed to fit a model (Equation 7) which provides the inputs to be used to calculate the volumes (Equation 1) with $\mathrm{r}^{2}=0.96$ and Syx $= \pm 0.07 \mathrm{~m}^{3}$.

$\frac{d_{i}}{d b h}=1.2033-3.9252\left(\frac{h_{i}}{h}\right)+16.4846\left(\frac{h_{i}}{h}\right)^{2}-36.6495\left(\frac{h_{i}}{h}\right)^{3}+36.6517\left(\frac{h_{i}}{h}\right)^{4}-13.7666\left(\frac{h_{i}}{h}\right)^{5}$

where:

$d_{i}$ is the diameter of section $\mathrm{i}(\mathrm{cm}) ; \mathrm{dbh}$ is the diameter at breast height $(\mathrm{cm})$ and; $h_{i}$ is the height of section i $(\mathrm{m})$.

The coefficient of variation (CV) (Table 1) for the different variables ranged from $4.3 \%$ to $14.3 \%$, with the plot volume (v) being the dendrometric property that presented the largest variability with a CV of $14.3 \%$, considered to be an intermediate variation according to the criteria proposed by Dalchiavon et al. (2012). These authors rank variability related to the magnitude of the coefficient of variation (CV) as low (CV < 10\%); intermediate $(10 \%<C V<20 \%)$; high (20\% < CV < 30\%) and; very high (CV > 30\%). Mello et al. (2005) found similar CV data for the volume of Eucalyptus grandis and Guedes et al. (2015) for Eucalyptus spp. Specifically, Vidaurre et al. (2015) found CVs of $4.36 \%$ and 3.03\%, considered a low variation for $\mathrm{dbh}$ and $\mathrm{h}$ respectively, in Eucalyptus benthamii at 5 years of age and with a $3 \times 3 \mathrm{~m}$ spacing.

The mean dbh was $13.96 \mathrm{~cm}$, which higher than reported by Maeda et al. (2015) for $E$. benthamii and lower than that found by Vidaurre et al. (2015) in $3 \times 3$ m spacing in Guarapuava (State of Paraná, Brazil), for the same species at the age of five years.

Table 1. Descriptive statistical analysis for the dendrometric characteristics evaluated.

\begin{tabular}{cccccccccc}
\hline Attrib. & $\mathbf{n}$ & Mean & Median & SD & CV (\%) & Min & Max & Cs & Ck \\
\hline $\mathrm{dbh}(\mathrm{cm})$ & 39 & 13.96 & 14.07 & 0.86 & 6.15 & 11.80 & 15.51 & -0.42 & -0.17 \\
$\mathrm{~h}(\mathrm{~m})$ & 39 & 21.21 & 21.22 & 0.92 & 4.32 & 18.99 & 23.20 & -0.37 & 0.18 \\
$\mathrm{hdom}(\mathrm{m})$ & 39 & 24.75 & 24.63 & 1.41 & 5.72 & 22.65 & 28.33 & 0.54 & -0.54 \\
$\mathrm{v}\left(\mathrm{m}^{3} / \mathrm{ha}\right)$ & 39 & 167.24 & 163.65 & 23.94 & 14.32 & 120.07 & 204.94 & -0.09 & -1.09 \\
\hline
\end{tabular}

dbh (diameter at breast height); h (total height); hdom (dominant height); v (volume); $n$ (number of observations); SD (standard deviation); CV (coefficient of variation); Cs (coefficient of asymmetry); Ck (coefficient of kurtosis);

Similarly, Higa And Pereira (2003) reported values for mean height of $21.22 \mathrm{~m}$ for eightyear-old stands of the same species in Colombo (State of Paraná, Brazil), while Vidaurre et al. (2015) found higher values $(24.64 \mathrm{~m})$ for the same species, but at the age of five years old.

The detection of spatial dependence by the adjustment of theoretical semivariograms to the experimental data are present in Table 2. For the plot volume (in $\mathrm{m}^{3}$ ), the model that best fit to the experimental data was the exponential, agreeing with results found by Mello et al. (2005), Mello et al. (2009) and Guedes et al. (2015). For height and dominant height, the spherical model was the one that fitted best to the semivariogram. According to Bottega et al. (2013), the exponential model and the spherical model represent mean and low continuity, respectively of spatial variability. Mello et al. (2005) also found isotropy for four dendrometric 
attributes, mean volume per hectare, mean average height, mean square diameter and mean basal area per hectare, in Eucalyptus plantations.

Table 2. Models and parameters of semivariograms of the dendrometric characteristics of E. benthamii.

\begin{tabular}{ccccccccc}
\hline Attribute & Model & $\mathbf{C}_{\mathbf{0}}$ & $\mathbf{C}_{\mathbf{0}}+\mathbf{C}$ & $\mathbf{A}_{\mathbf{0}}(\mathbf{m})$ & $\mathbf{r}^{\mathbf{2}}$ & $\mathbf{S Q R}$ & $\begin{array}{c}\mathbf{D S D} \\
\mathbf{( \% )}\end{array}$ & Class \\
\hline $\mathrm{dbh}$ & $\mathrm{exp}$ & 0.43 & 0.92 & 1010.70 & 0.53 & 0.04 & 46.41 & Interm. \\
$\mathrm{h}$ & $\mathrm{sph}$ & 0.21 & 1.07 & 290.00 & 0.55 & 0.21 & 0.20 & High \\
hdom & $\mathrm{sph}$ & 0.57 & 2.75 & 291.90 & 0.977 & 0.04 & 20.08 & High \\
$\mathrm{v}$ & $\exp$ & 26.00 & 568.8 & 98.4 & 0.25 & 4501.0 & 4.6 & High \\
\hline
\end{tabular}

$\mathrm{dbh}$ (diameter at breast height); $\mathrm{h}$ (total height); hdom (dominant height); $v$ (volume); sph: spherical; exp: exponential; $C_{0}$ : nugget effect; $C_{0}+C$ : sill; $A_{0}(m)$ : range of spatial dependence; $r^{2}$ : coefficient of determination; SQR: residual sum of squares; DSD (\%): degree of spatial dependence according to Cambardella et al. (1994).

The volume showed higher nugget effect and higher CV\% than the other parameters (Table 2), corroborating data of Siqueira et al. (2008) who made an analogy between the coefficient of variation $(\mathrm{CV})$ and nugget effect $\left(\mathrm{C}_{0}\right)$ values. They pointed out that the attributes, which represent higher coefficient of variation values, indicate a greater discontinuity among the samples. The nugget effect $\left(C_{0}\right)$ evaluates the stability of the data or the lack of change in their values as a function of the distance separating neighboring points; in some cases, the nugget effect can be attributed to measurement errors or because the data have not been collected at sufficiently close intervals; a similar behavior also reported by Barni et al. (2016).

Oliveira et al. (2018) found nugget effect values of 1.35 and 2.49 for dbh and volume, respectively, in 36 circular plots with a fixed area of $400 \mathrm{~m}^{2}$. According to the authors, the magnitude of the nugget effect is related to small-scale sampling and measurement errors. This is confirmed in the study of Amaral et al. (2013), who states that units should have a dimension appropriate to the objectives of the analysis; in this case to evaluate the spatial distribution of native species of a Mixed Ombrophilous Forest. According to these authors the sampling intensity ( 45 units) and the used plot size $(10 \times 50 \mathrm{~m})$ should be sufficient to prove the efficiency of the procedure for further estimation of species distribution by geostatistics. In this case, Mimosa scabrella (bracatinga) presented extremely long range and greater nugget effect, as well as smaller values for spatial dependence and sill, compared to the other species Ilex paraguariensis (yerba mate) and Dicksonia sellowiana (xaxim), causing greater discrepancies in the estimates of the highest values for the individuals of this species. According to the authors, this behavior is due to the low number of individuals present in the sample units, a result of disturbances caused by anthropic actions.

Through the nugget effect (CO), it was observed that the variance of the data at distances below the sample was greater for the volume when compared to the other variables. Thus, with the application of more intensive samplings, a more detailed spatial continuity of the volume would possibly be detected. Similar results were reported by Pelissari et al. (2014) in Tectona grandis stands.

The degree of spatial dependence (DSD\%) was verified from the relationship between the nugget effect and the threshold, as proposed by Cambardella et al. (1994). All the studied characteristics presented a high spatial dependence, except for the dbh, which presented intermediate spatial dependence. The dominant height presented a strong spatial correlation and this characteristic is considered by Mello et al. (2005) as a good indicator of the potential of the kriging technique for site classification.

The range indicates the limit of spatial dependence of a variable, so that determinations made at distances greater than this value will have random spatial distribution and are therefore independent, and may be applied to classical statistics (Gazolla-Neto et al., 2016). The larger this range, the greater the spatial continuity among the observations, which provides better estimates for kriging, while requiring fewer samples (Mello et al., 2005). The 
range is a particularly important parameter, since it helps other researchers to decide the spacing that they will use between sampling points (Lundgren et al., 2016). In our study, a range greater than the analyzed lag distance was observed and the theoretical range (given by the model) was $1.010 \mathrm{~m}$ (Figure 4a). According to Chung et al. (2014), a large range, greater than the active lag distance, means that the variable continues to exhibit spatial dependency past the maximum distance. However, if we used a lower active lag we would have less semivariance and, consequently, fewer pairs of points which could affect the reliability of the variogram.

The range for $h_{\text {dom }}(291.9 \mathrm{~m}$ ) was lower than that reported by Guedes et al. (2015). They studied spatial dependence for dendrometric variables in Eucalyptus spp. at different ages and observed a reduction in the range value with increasing age and at 3.7 years old, with a found range for hdom of $370.87 \mathrm{~m}$. However, we must emphasize that these parameters are influenced by the sampling performed, by the distance between the sampling points and by the characteristics of the stand. The height (h) reached similar range when compared to the $\mathrm{h}_{\mathrm{dom}}$, but the adjustment was worse (Figure $4 \mathrm{~b}$ ).

The $h_{\text {dom }}$ showed the lowest dispersion for the observed semivariance (Figure 4c), indicating a good correlation between the theoretical and experimental semivariograms $\left(r^{2}=0.97\right)$. On the other hand, the volume $(v)$ presented a low coefficient of determination and a higher residual sum of squares $(4,501)$, probably due to the second pairing and the higher lag in comparing to the others, reflected in a lowest $A_{0}$ and highest SQR (Figure $4 d$ ). In other words, the residual error contributed to a high $C_{0}$, which increases the sill $\left(C_{0}+C\right)$, in this case, related to the lower spatial variability to this dendrometric characteristic, resulting in the lower $r^{2}(0.25)$. According to Silveira (2008) this pattern suggest the data tends to behave randomly, related to the "pure nugget effect", proving the same behavior to the volume in the present analysis. When any autocorrelation is present (specially the large lags), the semivariance will tend to the variance of the data $\left(\sigma^{2}\right)$ (Cressie, 1993).

$\mathrm{dbh}$

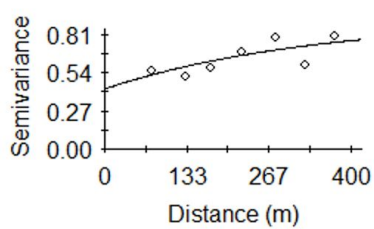

(a)

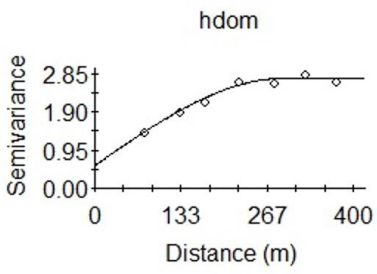

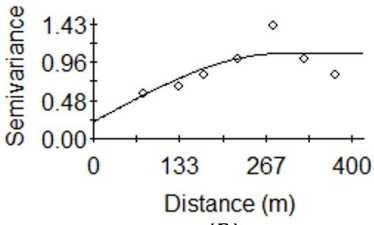

(D)

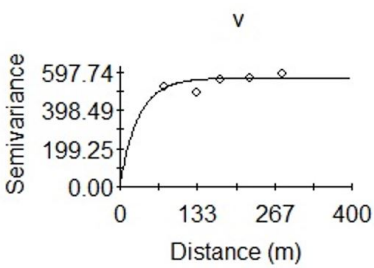

Figure 4. Semivariograms adjusted for the dendrometric variables studied.

The estimated values after the cross-validation showed the best fit for the dbh, $h$, and hdom (Figure $5 a ; 5 b$ and $5 c$, respectively). This can be done by observing the regression coefficient (or angular coefficient) of the dotted line, which, the closer to the observed values - which corresponds to the points that define the dashed line - the better the adjustment.

On the other hand, for plot volume (Figure $5 d$ ), it is observed that it was not possible to obtain good estimates from the model. Pelissari et al. (2015) studying the spatial distribution of the dominant height of Tectona grandis L.f. also found low values of coefficient of determination in cross-validation, but did not consider it necessarily incorrect, since these results are commonly found in spatial modeling. Pelissari et al. (2014) also found $r^{2}$ values higher than 0.9 in the semivariograms adjustment for volume and basal area of Tectona grandis at 5 years of age; in 
the cross-validation they found $r^{2}$ values close to 0.36 . Lundgren et al. (2016) used kriging to estimate the volume of 1875 eucalyptus trees. For the adjustment of semivariograms, the authors found $r^{2}$ values of 0.90, 0.59 and 0.63 , respectively, for sample size of 200, 100 and 50 trees. In kriging, $r^{2}$ values of $0.27,0.24$ and 0.05 , respectively, were found.

(a)

Cross-validation (hdom)

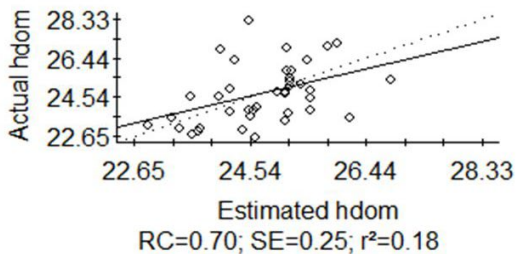

(c) (b)

Cross-validation (v)

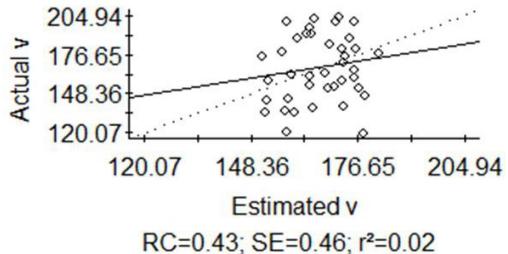

(d)

Figure 5. Cross-validation graphs and adjustment parameters: regression coefficient (RC), quadratic prediction error (SE) and; coefficient of determination $\left(r^{2}\right)$.

A comparative analysis between the interpolated values on the map from kriging and the actual values collected and processed through the forest inventory allow us to conclude that the models generated for $h$ and $h_{\text {dom }}$ were better compared to $d b h$ and $v$, since they presented greater correspondence between the values (Figure 6) .
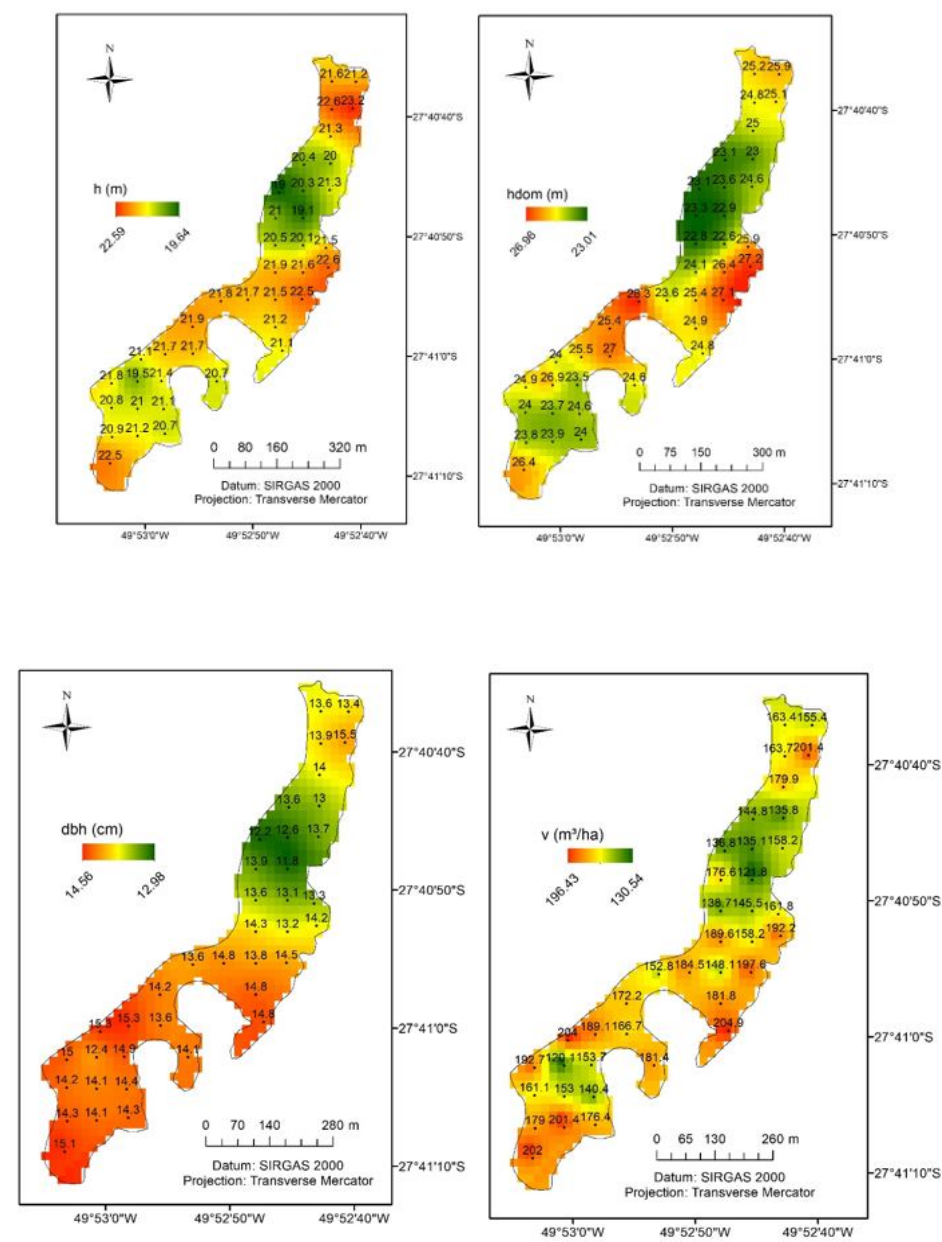

Figure 6. The spatial distribution of the dendrometric variables, obtained from the semivariograms model and the sampling points of the forest inventory. 
The lower part of the interpolation map of the $\mathrm{dbh}$ is presented as a region with high values, although, in some cases, the sampled plots had small dbh, indicating the low accuracy of the interpolation, with the same behavior evidenced for the volume interpolation map. Nevertheless, especially for volume, mismatches were found in some cases, which reduced the confidence of interpolation.

\section{CONCLUSIONS}

The kriging method was effective for the interpolation of $\mathrm{h}$ and hdom data in nonsampled locations, with the spherical model being the best spatial model for the semivariances, although the dbh presented an unsatisfactory fit. Therefore, it is proposed to consider increasing the number of samples in this area of study and also to sample smaller distances to increase the accuracy of estimates and the production of forest sites.

The spatial dependence structure was similar in all directions, suggesting that isotropic spatial continuity exists. In addition, the spatial component should be considered in forest inventory processing, and plots should not be treated as independent.

\section{ACKNOWLEDGMENTS}

The authors would like to thank the research funding agencies FAPESC (Foundation for Research and Innovation Support of the State of Santa Catarina) and CAPES (Coordination for the Improvement of Higher Education Personnel) for the doctorate and visitor graduate student scholarship granted to the first author. And also to Klabin for the financial support and area availability for this research.

\section{REFERENCES}

Amaral, L. P., Ferreira, R. A., Watzlawick, L. F., Longhi, S. J., \& Sebem, E. (2013). Influência da floresta alterada na distribuição espacial de três espécies da Floresta Ombrófila Mista avaliada pela geoestatística. Revista Árvore, 37(3), 491-501.

Arce, J. E., Koehler, C. B., \& Sanquetta, C. R. (2002). Florexel - Funções florestais desenvolvidas para o Microsoft Exce/C. Curitiba: Centro de Ciências Florestais e da Madeira - CCFM, UFPR.

Barni, P. E., Manzi, A. O., Condé, T. M., Barbosa, R. I., \& Fearnside, P. M. (2016). Spatial distribution of forest biomass in Brazil's state of Roraima, northern Amazonia. Forest Ecology and Management, 377, 170-181. http://dx.doi.org/10.1016/j.foreco.2016.07.010.

Bottega, E. L., Queiroz, D. M., Carvalho Pinto, F. D. A., \& Souza, C. M. A. (2013). Variabilidade espacial de atributos do solo em sistema de semeadura direta com rotação de culturas no Cerrado brasileiro. Revista Ciência Agronômica, 44(1), 1-9.

De Bruin, S., Ballari, D., \& Bregt, A. (2012). Where and when should sensors move? Sampling using the expected value of information. Sensors (Basel), 12(12), 16274-16290. PMid:23443379. http://dx.doi.org/10.3390/s121216274.

Cambardella, C. A., Moorman, T. B., Novak, J. M., Parkin, T. B., Karlen, D. L., Turco, R. F., \& Konopka, A. E. (1994). Field scale variability of soil properties in central lowa soils. Soil Science Society of America Journal, 58(9), 1501-1511. http://dx.doi.org/10.2136/sssaj1994.03615995005800050033x.

Chung, S., Sudduth, K. A., Drummond, S. T., \& Kitchen, N. R. (2014). Spatial variability of soil properties using nested variograms at multiple scales. Journal of Biosystems Engineering, 39(4), 377-388. http://dx.doi.org/10.5307/JBE.2014.39.4.377.

Cressie, N. A. C. (1993). Statistics for Spatial Data. New York: John Wiley \& Sons.

Dalchiavon, F. C., Carvalho, M. D. P., Andreotti, M., \& Montanari, R. (2012). Variabilidade espacial de atributos da fertilidade de um Latossolo Vermelho Distroférrico sob Sistema Plantio Direto. Ciência Agronômica, 43(3), 453-461. http://dx.doi.org/10.1590/S1806-66902012000300006.

Environmental Systems Research Institute - ESRI. (2013). ArcGIS for Desktop. Versão. 10.3. Redlands: ESRI.

Figueiredo Filho, A., Retslaff, F. A. S., Kohler, S. V., Becker, M., \& Brandes, D. (2015). Efeito da idade no afilamento e sortimento em povoamentos de Araucaria angustifolia. Floresta e Ambiente, 22(1), 50 59. http://dx.doi.org/10.1590/2179-8087.080114. 
Gazolla-Neto, A., Fernandes, M. C., Vergara, R. D. O., Gadotti, G. I., \& Villela, F. A. (2016). Spatial distribution of the chemical properties of the soil and of soybean yield in the field. Ciência Agronômica, 47(2), 325-333. http://dx.doi.org/10.5935/1806-6690.20160038.

Guedes, I. C. D. L., Mello, J. M. D., Silveira, E. M. D. O., Mello, C. R. D., Reis, A. A. D., \& Gomide, L. R. (2015). Continuidade espacial de características dendrométricas em povoamentos clonais de Eucalyptus sp. avaliada ao longo do tempo. Cerne, 21(4), 527-534.

Higa, R. C. V., \& Pereira, J. C. D. (2003). Usos Potenciais do Eucalyptus benthamii Maiden et Cambage (Comunicado Técnico, 100, 4 p.). Colombo: Embrapa Florestas.

Indústria Brasileira de Árvores - IBA. (2017). Relatório IBA 2017. São Paulo: IBA.

Lundgren, W. J. C., Silva, J. A. A. S., \& Ferreira, R. L. C. (2016). Influência do tipo de amostragem na estimativa de volume de madeira de eucalipto por krigagem. Floresta e Ambiente, 24(4), 511-523.

Maeda, S., Gomes, J. B. V., \& Bognola, I. A. (2015). Crescimento de Eucalyptus benthamii submetido à aplicação de lama de cal e cinza de madeira (Comunicado Técnico, 373, 9 p.). Colombo: Embrapa Florestas.

Mello, J. M., Diniz, F. S., Oliveira, A. D., Mello, C. R., Scolforo, J. R. S., \& Acerbi, F. W. A. (2009). Continuidade espacial para características dendrométricas (número de fustes e volume) em plantios de Eucaliptus grandis. Árvore, 33(1), 185-194.

Mello, J. M., Batista, J. L. F., Oliveira, M. S., \& Ribeiro, P. J. (2005). Estudo da dependência espacial de características dendrométricas para Eucalyptus grandis. Cerne, 11(2), 113-126.

Oliveira, I. M. S.., Silveira, E. M. O., Paiva, L., Acerbi Junior, F. W., Mello, J. M. (2018). Remote Sensing and Geostatistics Applied to Post-stratification of Eucalyptus Stands. Floresta e Ambiente, 25(3).

Pelissari, A. L., Figueiredo, A. F., Caldeira, S. F., \& Machado, S. A. (2014). Geoestatística aplicada ao manejo de povoamentos florestais de teca, em períodos pré-desbaste seletivo, no estado do Mato Grosso. Revista Brasileira de Biometria, 32(3), 430-444.

Pelissari, A. L., Caldeira, S. F., Filho, A. F., \& Machado, S. A. (2015). Propostas de mapeamentos da capacidade produtiva de sítios florestais por meio de análises geoestatística. Scientia Forestalis, 43(107), 601-608

Prodan, M., Peters, R., Cox, F., Real, P. (1997). Mensuração florestal (586 p.). San José, Costa Rica: IICA.

R Core Team (2018). R: a language and environment for statistical computing. Vienna: R Foundation for Statistical Computing.

Robertson, G. P. (2008). GS+: Geostatistics for the environmental sciences (179 p.). Plainwell, Michigan USA: Gamma Design Software.

Sanquetta, C. R., Watzlawick, L. F., Corte, A. P. D., \& Fernandes, L.A. V. (2009). Inventários Florestais: Planejamento e Execução (2 ${ }^{\mathrm{a}}$ ed., Vol. 1, 307 p.). Curitiba: Multigraphics.

Schöpfer, W. (1966). Automatisierung der Massen, Sorten und Wertberechnung stehender Waldbestände (Schriftenreihe Bad Koblenz: Württ-Forstbl). Berlim: Wurtt-Forstl.

Santos, H. G., Jacomine, P. K. T., Anjos, L. H. C., Oliveira, V. A., Lumbreras, J. F., Coelho, M. R., Almeida, J. A., Cunha, T. J. F., \& Oliveira, J. B. (2013). Sistema brasileiro de classificação de solos (3a ed., 353 p.). Brasília, DF: Embrapa.

Schabenberger, O., \& Gotway, C. A. (2017). Statistical methods for spatial data analysis (488 p.). New York: Chapman and Hall. http://dx.doi.org/10.1201/9781315275086.

Silveira, C. T. D. (2018). Análise espacial da vegetação arbórea em parcela de estepe estacional savanícola no Parque Estadual do Espinilho, RS (Master's Dissertation). Universidade Federal de Santa Maria, Santa Maria, RS. 46 p. Retrieved in 2018, September 21, from: http://repositorio.ufsm.br/bitstream/handle/1/13021/DIS_PPGAP_2018_SILVEIRA_CASSIO.pdf?seque nce=1\&isAllowed=y

Siqueira, G. M., Vieira, S. R., \& Ceddia, M. B. (2008). Variabilidade de atributos físicos do solo determinados por métodos diversos. Bragantia, 67(1), 203-211.

Soil Survey Staff Keys to soil taxonomy (12th ed.) Washington, DC: USDA-Natural Resources Conservation Service; 2014. 360 p.

Souza, R. M. S., Almeida, A. Q. D., Ribeiro, A., Souza, E. S. D., \& Leite, F. P. (2015). Evaluation of the spatial dependence of dendrometric characteristics for a Eucalyptus plantation. Acta Scientiarum, Agronomy, 37(4), 483-488. 
Ver Hoef, J. M., \& Temesgen, H. (2013). A comparison of the spatial linear model to nearest neighbor (kNN) methods for forestry applications. PLoS One, 8(3), e59129. PMid:23527110. http://dx.doi.org/10.1371/journal.pone.0059129.

Vidaurre, G. B., Nutto, L., França, F. J. N., Braz, R. L., Watzlawick, L. F., \& Moulin, J. C. (2015). Tensão de crescimento no lenho de Eucalyptus benthamii e sua relação com características dendrométricas em diferentes espaçamentos. Floresta e Ambiente, 22(3), 408-415. http://dx.doi.org/10.1590/21798087.044413.

Wrege, M. S., Steinmetz, S., Reisser Júnior, C., \& Almeida, I. R. (2012). Atlas Climático da Região Sul do Brasil: Estados do Paraná, Santa Catarina e Rio Grande do Sul (333 p.). Brasília, DF: Embrapa.

Authors' contributions: L.C.G.G.: Conceptualization, data curation, formal analysis, funding acquisition, methodology, project administration, resources, sample collection and preparation, software, writing-original draft preparation, writing_-review and editing; I.S.N.: methodology, Software, Validation, Visualization, writingreview and editing; D.J.M.: Conceptualization, data curation, formal analysis, funding acquisition, methodology, project administration, resources, software, supervision; S.X.C.: Conceptualization, funding acquisition, resources, writing_review and editing; E.A.S.: methodology, writing-review and editing.

The article is part of the Doctoral Thesis of the first author presented to the State University of Santa Catarina -UDESC, by the Graduate Program in Soil Science. 